\title{
IN VIVO AND IN VITRO ASSESSMENT OF THE ANDROGENIC POTENTIAL OF A PULP AND PAPER MILL EFFLUENT
}

\author{
Rosanne J. Ellis, $\dagger$ Michael R. van den Heuvel, $* \dagger$ Emil Bandelj, $\ddagger$ Murray A. Smith, $\dagger$ \\ Lynda H. McCarthy, $†$ Trevor R. Stuthridge, $\dagger$ and Daniel. R. Dietrich $\$$ \\ †Forest Research, Private Bag 3020, Sala Street, Rotorua, New Zealand \\ $\ddagger$ Ryerson Polytechnic University, 350 Victoria Street, Toronto, Ontarjo M5B 2K3, Canada \\ §University of Konstanz, Jacob-Burckhardt Street 25, Konstanz, Germany
}

\begin{abstract}
The androgenic potential of a New Zealand pulp and paper mill effluent was measured by applying a combination of in vitro and in vivo bioassays with mosquitofish (Gambusia affinis) and goldfish (Carassius auratus). The in vivo method assessed the rate of gonopodial development (masculinization) and alterations from normal reproductive behavior in adult female mosquitofish exposed for $21 \mathrm{~d}$ to untreated or secondary-treated pulp mill effluent. A second in vivo mosquitofish exposure tested the effect of glass-fiber (type C) filtration of secondary-treated effluent on rates of expression of the same endpoints. Extractable organics analyses of effluents and extracts thereof were conducted. Mosquitofish demonstrated significant masculinization on exposure to either treated or untreated effluent; the frequency of gonopodial development was reduced with effluent secondary-treatment. Male mating behavior was observed in the masculinized adult females. Glass-fiber (type F) filtration of the treated effluent eliminated the masculinizing effect, suggesting that the bioactive compounds were associated with the suspended solids. The in vitro method measured the binding of compounds within a treated thermomechanical/bleached kraft effluent extract to androgen receptors contained in goldfish testis cytosol. Exposure to extracts of either the particulate (glass-fiber filtered) or the dissolved organic fraction of the effluent produced significant binding (as indicated by the displacement of radiolabeled testosterone) to the androgen receptor in goldtish gonadal tissue. Thus, the dissolved organics extract of the treated effluent contained compounds androgenic to goldfish in vitro but not to mosquitofish in vivo. The combined in vitro and in vivo data suggest that the effuent in question could exert effects on the reproductive physiology of fishes through an androgenic mechanism. The androgenic compounds androstenedione and testosterone were not detected in the extracts used for the in vitro component of this study.
\end{abstract}

Keywords-Androgen receptor Masculinization Fish Pulp Paper

\section{INTRODUCTION}

Reproductive impairment in fishes exposed to pulp and paper mill effluent has been reported as reduced plasma sex steroid concentrations $[1,2]$, decreased egg and gonad size [36], reduced fertilization and hatching success [7,8], decreased occurrence of male secondary sex characteristics, and greater age to maturity [9]. Some documented responses mimic the physiological effects of natural androgens. Sex ratios strongly skewed toward male offspring were observed in bleached kraft mill effluent (BKME)-exposed eelpout [10] and fathead minnows [11]. Development of male sex characteristics in response to pulp mill effluent exposure was observed in female guppies (red body coloration [12]) and mosquitofish (development of a gonopodium [13]; expression of male sexual behavior [14]). Exposure of newly born mosquitofish to whole BKME resulted in precocious male development and subsequent reduced adult size [15]. Male gonadal tissue was present in the ovaries of female goldfish exposed to BKME [16].

Some associated reproductive effects noted in fishes have not been androgenic. A number of studies have highlighted estrogenic activity in pulp and paper mill effluent, including the elevation of plasma vitellogenin (VTG) and VTG gene expression in the livers of exposed males or juveniles [1719]. Extracts of liver tissue from white sucker experimentally

* To whom correspondence may be addressed (mike.vandenheuvel@forestresearch.co.nz). exposed to BKME in the field demonstrated binding affinity with both goldfish estrogen and androgen receptors [20].

It is known that pulp and paper mill wastewaters contain wood extractives, processing additives, and other compounds that are potentially capable of endocrine modulation. These compounds include phytosterols, resin acids, polycyclic aromatic hydrocarbons (PAHs), surfactants, and organochlorines. However, plant sterols were suggested as the chief source of androstane steroids in pulp mill effluent [14]. Previous research demonstrated that plant sterols such as $\beta$-sitosterol, stigmasterol, and stigmastanol may be broken down by microorganisms in culture to produce androgenic steroids or androstanelike compounds [21]. Denton et al. [22] have shown that byproducts of microbial-degraded stigmastanol and $\beta$-sitosterol can exert morphogenic effects in female mosquitofish that are similar to those observed by Turner [23] and Howell et al. [13] on exposure to androgens. Recently, androstenedione was identified as one of two androgenic compounds within BKMEreceiving water fractions collected where a population of masculinized mosquitofish was found [24].

The primary goal of this study was to ascertain if a secondary-treated, elemental-chlorine-free New Zealand pulp and paper mill effluent would induce abnormal morphogenic responses and altered behavior in adult female mosquitofish (Gambusia affinis). The study also sought to establish if secondary treatment of effluent or subsequent filtration of the treated effluent affected rates of expression of morphogenic and behavioral responses. Concurrently with the mosquitofish 
study, the goldfish (Carassius auratus) androgen receptorbinding bioassay was used to further characterize the androgenic properties of the treated effluent extracts. Finally, concentrations of the androgens testosterone and androstenedione were measured in the effluent and effluent extracts.

\section{MATERIALS AND METHODS}

\section{Mill description}

The Tasman Mill (Kawerau, New Zealand) is an integrated bleached kraft and thermomechanical pulp and paper mill ( 760 and 1,010 air-dried tonnes/d, respectively). Mill furnish was primarily softwood (Pinus radiata) with the occasional use of eucalypt. The bleaching process was elemental-chlorine-free with either sodium hypochlorite or chlorine dioxide (DEopDnD or DeopPD). The wastewater treatment system has a pretreatment moving bed biofilm reactor, which treats effluent from the thermomechanical pulp mill in order to reduce the biological oxygen demand of the combined effluent. The pretreated thermomechanical effluent was then combined with BKME and passed through two bar screens and a clarifier (no flocculation used) prior to secondary treatment in a three-pond aerated stabilization basin. The treatment ponds had a combined area of 45 ha and provide an effluent retention time of 5 to $6 \mathrm{~d}$. Following treatment, effluent is discharged into the Tarawera River at a total mean volume of $180,000 \mathrm{~m}^{3} / \mathrm{d}$ and at an average temperature of 26 to $28^{\circ} \mathrm{C}$. The effluent dilution in the Tarawera River ranges between 5 and $12 \%$.

\section{Mosquitofish collection}

This study focuses on changes in the reproductive morphology of adult female western mosquitofish, G. affinis. Typical to the Poeciliidae family, mosquitofish display strong sexual dimorphism; females average $60 \mathrm{~mm}$ fork length, while males average $35 \mathrm{~mm}$, and males possess a modified anal fin that functions as a gonopodium. The gonopodium is an intromittent organ used during copulation [25]; the tip has hooks and spines that act as a grasping device during sperm transfer. The anal fin of females continues to grow proportionately to body size throughout life, whereas in males the modification of the anal fin is hormone dependent (under androgenic control), and at sexual maturity, growth in body size and gonopodia stops [25].

Mosquitofish were captured from a population in the University of Waikato campus lakes (Hamilton, New Zealand). Fish were caught using hand nets and transported to the laboratory where the sexes were separated and allowed to acclimate for two weeks. Sexually mature females were selected on the basis of the absence of a gonopodium and by size (greater than $35 \mathrm{~mm}$ ).

\section{In vivo mosquitofish experimental design and exposure}

Prior to mosquitofish chronic exposures, standard static 96h median lethal concentration (LC50) tests ( $n=10$ fish/concentration) were conducted to determine the lethality thresholds of the effluents used. These data were used to set the concentrations of chronic tests at nonlethal levels. All mosquitofish exposures were conducted under a 12:12-h photoperiod, with gentle aeration in treatment aquaria and water temperatures maintained at 26 to $28^{\circ} \mathrm{C}$. Each treatment consisted of four replicates of six fish. The test volume per replicate was $4 \mathrm{~L}$ with a $50 \%$ daily static renewal.

Exposures were performed either with effluent collected at the inlet of the primary treatment pond or with effluent from postsecondary treatment, collected immediately before discharge into the Tarawera River (New Zealand). These are henceforth referred to as the untreated and secondary-treated effluents, respectively. Effluents were transported to the laboratory in $20-\mathrm{L}$ polyethylene carboys and stored at $4^{\circ} \mathrm{C}$ within i h of collection. All samples were shaken vigorously prior to use in daily effluent replacements. Dechlorinated Rotorua City (New Zealand) tap water (sourced from an aquifer) was used for reference and diluent waters.

Two experiments were conducted during this study, both 21-d exposures to the effluents described previously. Experiment 1 was initiated in December 1998 and experiment 2 in July 1999. The first experiment compared untreated effluent diluted to $15 \%$ volume/volume $(\mathrm{v} / \mathrm{v})$ of the original concentration with sccondary-treated effluent at 15 and $70 \% \mathrm{v} / \mathrm{v}$ dilution. The second experiment compared filtered and unfiltered secondary-treated effluent (both at $15 \% \mathrm{v} / \mathrm{v}$ dilution). Filtration was conducted immediately after effluent collection using 15 $\mathrm{cm}$ Whatman glass-fiber filters (GF/C; Fairfield, NJ, USA). Filtrate and filter papers were stored at $-20^{\circ} \mathrm{C}$ pending organics analysis. Quantities needed for $50 \%$ daily renewals were aliquoted once filtration was completed and stored at $4^{\circ} \mathrm{C}$ for all $21 \mathrm{~d}$ of the experiment.

In both experiments, mosquitofish gonopodial development was assessed. In order to quantify and interpret the degree of anal fin modification, morphological changes in the female anal fin were monitored daily by visual observation. At the termination of the experiment $(21 \mathrm{~d})$, only those fish with the addition of new segments to the third and fourth rays giving appearance of elongation were considered as masculinized. This was determined using a dissecting microscope. This also included fish that were further masculinized and exhibited third-, fourth-, and fifth-ray fusion and elongation or full development of gonopodium to the length of a normal male. Individuals were sacrificed, and female gender was verified under a dissecting microscope by presence of ovaries.

Prior to the termination of experiment one, a 15-min ethogram was compiled on one replicate per treatment. Five malereproductive behavioral characteristics were looked for over a 15-min interval, following the protocol and descriptions of Bortone et al. [26]. The five behaviors monitored were as follows: approach-fish slowly, deliberately moving toward another; chase-fish abruptly moving toward another; display-fish's body remaining rigid, quivering slightly with fins held erect; thrust-fish maneuvering erect anal fin toward the gonopore of another fish; and penetrate-fish making contact with gonopore of another fish.

\section{In vitro goldfish androgen receptor bioassay}

A 20-L sample of treated effluent was filtered through GF/

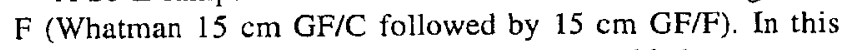
particular extraction, the GF/F filters were added to capture any remaining solids, as they have slightly smaller pore size than GF/C. However, the majority of solids was observed to be removed by GF/C, and very little was retained on GF/F, so the pooled GF/C and GF/F filters would not be expected to increase the amount of filtered biosolids significantly as compared to GF/C alone that was used in the in vivo experiment. The remaining dissolved organic compounds were removed from the filtrate by solid-phase extraction using SPEC $47-\mathrm{mm}$ C18AR solid-phase extraction disks (ANSYS Diagnostics, Lake Forest, CA, USA). The combined glass-fiber filters and solid-phase extraction (C-18) disks were soxhlet extracted us- 
ing dichloromethane, and extracts were reduced in volume by rotary evaporation and solvent exchanged into methanol. The methanol extracts were further reduced to a final volume of $4 \mathrm{ml}$.

The androgen receptor bioassay was performed according to the method developed by Wells and Van Der Kraak [27] Goldfish testes were pooled and homogenized in ice-cold TEG buffer $(50 \mathrm{nM}$ Tris-HCl, $1 \mathrm{mM}$ NaEDTA, $30 \%$ glycerol, $\mathrm{pH}$ 7.5 ) and centrifuged at $10,000 \mathrm{~g}$ at $4^{\circ} \mathrm{C}$. The supernatant was then ultracentrifuged at $100,000 \mathrm{~g}$ at $4^{\circ} \mathrm{C}$. The cytosolic fraction was charcoal stripped ( $1 \%$ charcoal, $0.1 \%$ dextran) to remove endogenous steroids. For each binding assay, the cytosolic fraction was diluted in TEG buffer, and effluent-methanol extract was then added ( $2 \% \mathrm{v} / \mathrm{v}$ methanol). The treatment mixture was incubated with ${ }^{3} \mathrm{H}$-testosterone $\left(\left[1,2,6,7-{ }^{3} \mathrm{H}\right]\right.$ testosterone, $100 \mathrm{Ci} / \mathrm{mmol}$; Amersham, Oakville, ON, Canada) at $4^{\circ} \mathrm{C}$ for $18 \mathrm{~h}$. At the end of the $18-\mathrm{h}$ incubation period, dextran-coated activated carbon was added to each sample, and the samples were centrifuged at $1,000 \mathrm{~g}$. The resultant supernatant was counted on a scintillation counter. Analysis of the binding curves using a nonlinear one-site ligand-binding model indicated a high affinity, low-capacity binding site with $K_{\mathrm{u}}=3.64 \mathrm{nM}$ and $\mathrm{B}_{\max }=687 \mathrm{fmol} / \mathrm{mg}$ protein. This result was consistent with estimates presented by Wells and Van Der Kraak and concluded by them to indicate androgen receptor binding [27]. For binding curves with effluent extracts, methanol carrier was added to all nonextract samples (including blanks and testosterone standards). A testosterone standard curve was run with every assay in order to quantify the potency of the effluent extracts. Three replicates of each point on the curve were performed for all assays.

\section{Extractable organics analysis}

Effluent chemical parameters were measured over the period when the mosquitofish experiments took place. Untreated secondary-treated, and filtered secondary-treated effiuent samples were spiked with surrogate standards [28] $(2,4,6$-tribromoanisole, 2,4,6-tribromophenol, $\mathrm{D}_{10}$-anthracene, $\mathrm{D}_{31}$-palmitic acid, 8[14]-abietenic acid and dihydrocholesterol) and extracted by continuous liquid-liquid extraction with dichloromethane at $\mathrm{pH} 9$. The use of an extraction $\mathrm{pH}$ of 9.0 ionizes the high-molecular-weight phenolic compounds than occur in pulp and paper effluents. This reduces the adsorption of hydrophobic organics to the dissolved organic carbon, resulting in more complete extraction. At this $\mathrm{pH}$, the equilibrium of organic acids favors the aqueous phase. However, the countercurrent liquid-liquid extractors extract these analytes incrementally in many steps (similar to soxhlet extraction), resulting in effectively complete extraction from the aqueous phase.

The extract solvent volume was reduced by rotary evaporation, and samples were dried with anhydrous sodium sulfate and then derivatized (silylation) for analysis by gas chromatography with mass selective detection (GC-MSD). Extracts produced for goldfish in vitro exposures were similarly analyzed by gas chromatography with mass selective detection. All organics were corrected for extraction blanks and adjusted for the recovery of appropriate surrogate. The classes of compounds that were quantified in effluent were phenolics, terpenes, fatty acids, resin acids, resin acid neutrals, and phytosterols.

\section{Analysis of steroid hormones in effluent extracts}

Secondary treated effluent extracts used for in vitro goldfish exposures were assayed for the androgenic hormones testos- terone and androstenedione using liquid chromatography/mass spectrometry. Extracts were filtered with a $0.45-\mu \mathrm{m}$ polytetrafluoroethylene $25-\mathrm{mm}$ syringe filter prior to chromatographic separation on a Prodigy ODS $3(1 \times 150 \mathrm{~mm}, 5 \mu \mathrm{m}$; Phenomenex, Torrance, CA, USA) reverse-phase column. A Thermo Finnigan (San Jose, CA, USA) Surveyor pump was used to deliver a flow rate of $100 \mu \mathrm{l} / \mathrm{min}$ gradient elution of water: methanol at $26^{\circ} \mathrm{C}$. The proportion of methanol was held at $40 \%$ for $6 \mathrm{~min}$ and then ramped up to $90 \%$ over $20 \mathrm{~min}$. A Thermo Finnigan liquid chromatography/mass spectrometry Deca XP ion-trap mass spectrometer interfaced with an electrospray ionization source was used to quantify androstenedione and testosterone in the extracts. The interface parameters were optimized using flow-injection analysis of testosterone and androstenedione. The nitrogen sheath gas flow was set to $27 \mathrm{psi}$, and the capillary temperature was maintained at $275^{\circ} \mathrm{C}$. The spray voltage was set to $4,500 \mathrm{~V}$, and the electron multiplier voltage was $850 \mathrm{~V}$. Ions produced were quantified using single-ion monitoring of the molecular $\left[\mathrm{M}^{+}\right]$ion in positive mode. Under these detector conditions, the liquid chromatography/mass spectrometry was calculated to be sensitive to 1 $\mathrm{ng} / \mathrm{ml}$ with a linear calibration range to $200 \mathrm{ng} / \mathrm{ml}$. To eliminate matrix interference as a possible reason for nondetection, effluent extracts were spiked to a concentration of $10 \mathrm{ng} / \mathrm{ml}$. Androstenedione and testosterone were both recovered in the matrix spike.

\section{Statistical analyses}

The LC50 for 96-h acute lethality tests was determined using trimmed Spearman-Karber analysis. Gonopodial development data approximated a binomial distribution. The expected frequency of masculinization in female mosquitofish was calculated from all reference treatments for these experiments $\left(p_{\text {mase }}=0.042\right)$. Based on the expected frequency for spontaneous masculinization in the test population, a binomial probability table was created ( $n=24$ for all treatments). From this table, the cumulative probability of occurrence of the observed rates and any rates greater than the observed reference rate of masculinization was calculated. The critical level of significance for analyses was assessed at $p<0.05$. Analysis of dose-response curves was performed with a logistic function using the GraphPad Prism 3 software package (San Diego, CA, USA). Testosterone-equivalent concentrations were generated from the ratio of the testosterone median effective concentration (EC50) (nM) to that of the extract EC50 (arbitrary dilution factor).

\section{RESULTS}

\section{Effluent characterization}

Over the period of both experiments, mean chemistry values for $100 \%$ secondary-treated effluent were as follows: conductivity of $910 \mu \mathrm{s} / \mathrm{cm}$, total suspended solids of $33.8 \mathrm{mg} / \mathrm{L}$, $\mathrm{pH} 7.4$, and adsorbable organic halogens of $1.2 \mathrm{mg} / \mathrm{L}$. Resin acids characteristic of softwood pulping were the most concentrated extractives found in both treated and untreated effluent at 1,152 and $17,207 \mu \mathrm{g} / \mathrm{L}$ total concentrations, respectively (Table 1). Substantial amounts of resin acid biotransformation products (intermediates in resin acid degradation and resin acid neutrals) were present in secondary-treated effluent. Resin acid neutrals were not detected in untreated effluent and thus appeared to be formed during biological treatment in the aerated stabilization pond system. The combined 
Table 1. Mean organics concentrations ( $\mu \mathrm{g} / \mathrm{L}$, CAS numbers in parentheses if available) in $100 \%$ untreated effluent, $100 \%$ secondary-tieated effluent used in the mosquitofish experiments sampled over three months $(n=7)$, and secondary-treated effluent extracts used in the goldfish bioussay (expressed as concentration in the effluent extracted). The estimated proportion of organics bound to particulates is presented as the percentage of total organics measured on filter paper (\%)

\begin{tabular}{|c|c|c|c|c|c|c|}
\hline \multirow[b]{2}{*}{ Compound } & \multicolumn{2}{|c|}{ Untreated effluent } & \multicolumn{2}{|c|}{ Treated effluent } & \multicolumn{2}{|c|}{ Treated effluent extracts } \\
\hline & Concn. & $\begin{array}{c}\% \text { of } \mathrm{GF}^{\mathrm{a}} / \\
\mathrm{C} \text { filter }\end{array}$ & Conen. & $\begin{array}{c}\% \text { of } \mathrm{GF} / \\
\mathrm{C} \text { filter }\end{array}$ & Concn. & $\begin{array}{c}\% \text { of } \mathrm{GF} \\
\mathrm{C} \text { filter }\end{array}$ \\
\hline \multicolumn{7}{|l|}{ Resin acid neutrals } \\
\hline Fichtelite (2221-95-6) & $<0.1$ & $\ldots$ & 11 & 94.2 & 20.7 & 88.2 \\
\hline Dehydroabietin & $<0.1$ & - & 1.5 & 87.7 & 4.7 & 71.2 \\
\hline Tetrahydroretene & $<0.1$ & - & 20.8 & 86.4 & 32.0 & 78.1 \\
\hline Retene $(483-65-8)$ & $<0.1$ & - & 16.2 & 84.9 & 11.7 & 79.1 \\
\hline Methyldehydroabietin & $<0.1$ & 一 & 1.8 & 73.6 & 1.0 & 90.3 \\
\hline Total & $<0.1$ & & 51 & & 70 & \\
\hline \multicolumn{7}{|l|}{ Resin acids } \\
\hline Pimaric acid $(127-27-5)$ & $1,011.2$ & 12.2 & 60.7 & 67.7 & 87.1 & 67.1 \\
\hline Sandaracopimaric acid (471-74-9) & 62.2 & 14.8 & 15 & 74.8 & 8.2 & 64.3 \\
\hline Isopimaric acid $(5835-26-7)$ & 391.1 & 13.7 & 30.1 & 72.2 & 49.1 & 72.2 \\
\hline Palustric acid (1945-53-5) & $1,330.6$ & 8.9 & 23.3 & 89.4 & $<0.1$ & - \\
\hline Dehydroabietic acid $(1740-19-8)$ & $1,809.7$ & 5.3 & 83.7 & 68.0 & 121.7 & 70.6 \\
\hline Abietic acid (514-10-3) & $9,226.2$ & 9.8 & 151.9 & 78.0 & 306.2 & 60.6 \\
\hline Neoabietic acid (471-77-2) & 2,980 & 9.4 & 9.3 & 97.1 & $<0.1$ & - \\
\hline Pimarenic acid & $<0.1$ & - & 25.2 & 71.1 & 31.6 & 79.4 \\
\hline Sandaracopimarenic acid & $<0.1$ & - & 54.2 & 56.9 & 43.2 & 76.4 \\
\hline Isopimarenic acid & $<0.1$ & - & 75.3 & 70.2 & 40.9 & 74.8 \\
\hline 13-Abietenic acid & 30.2 & 15.4 & 176.6 & 69.9 & 124.4 & 76.5 \\
\hline Pimaranic acid & $<0.1$ & - & 21.7 & 75.0 & 36.6 & 78.9 \\
\hline Isopimaranic acid & $<0.1$ & - & 16.1 & 75.9 & 12.3 & 70.5 \\
\hline Abictanic acid & $<0.1$ & - & 216.9 & 73.9 & 117.3 & 79.0 \\
\hline Seco-1-dehydroabietic acid & 73.6 & 8.8 & 111.5 & 40.1 & 87.8 & 67.9 \\
\hline Seco-2-dehydroabietic acid & 40.6 & 7.9 & 62.1 & 34.7 & 37.7 & 60.7 \\
\hline 12-Chlorodehydroabietic acid (57055-39-6) & 14.3 & 15.4 & 2.4 & 92.5 & $<0.1$ & - \\
\hline 14-Chlorodehydroabietic acid (57055-39-6) & 32.4 & 10.3 & 8.8 & 89.3 & 10.9 & 57.3 \\
\hline 12,14-Dichlorodehydroabietic acid $(57055-39-7)$ & $<0.1$ & - & 0.7 & $>75.0$ & $<0.1$ & - \\
\hline 7-Oxodehyóroabietic acid $(18684-55-4)$ & 65.9 & - & 1.3 & 78.5 & $<0.1$ & - \\
\hline Total & 17,068 & & 1,147 & & 1,115 & \\
\hline \multicolumn{7}{|l|}{ Phytosterols } \\
\hline Cholesterol $(57-88-5)$ & $<0.1$ & - & 32.2 & 85.1 & $<0.1$ & - \\
\hline Campesterol (474-62-4) & 0.8 & 100 & 7.6 & 93.7 & 6.8 & 98.5 \\
\hline Stigmasterol (83-48-7) & $<0.1$ & - & 21.2 & 88.1 & $<0.1$ & - \\
\hline$\beta$-Sitosterol (83-46-5) & 52.3 & 40.5 & 165.4 & 87.8 & 147.8 & 71.6 \\
\hline$\beta$-Sitostanol $(8.3-45-4)$ & 0.8 & 100 & 61.2 & 84.8 & 24.0 & 54.2 \\
\hline Total & 54 & & 288 & & 179 & \\
\hline
\end{tabular}

" $G F=$ glass-fiber filter.

primary and secondary treatment systems achieved greater than $90 \%$ removal of resin acids. Most of the resin acids were in solution in the untreated effluent rather than on particulate matter. The converse was true for secondary-treated effluent, where most organics were associated with filtered biosolids (Table 1). Total phenolics (>90\% guiacol; data not shown) were almost totally removed by treatment, showing a reduction from $277 \mu \mathrm{g} / \mathrm{L}$ in untreated effluent to $1 \mu \mathrm{g} / \mathrm{L}$ in treated effluent.

Mean phytosterol concentrations in treated and untreated effluents were 287 and $53.9 \mu \mathrm{g} / \mathrm{L}$, respectively (Table 1). As it was unlikely that significant levels of phytosterols could be produced in the treatment system, this difference may be accounted for by differences in timing of collection of effluent samples and probably reflects the high degree of variability in the chemistry of mill effluent [29]. The $\beta$-sitosterol was the dominant compound accounting for more than half the total phytosterols in both effluents. Within untreated effluent, less than half the $\beta$-sitosterol was bound to the filtered solids; 80 to $90 \%$ of all the phytosterols detected in treated effluent were bound to solids.
The differences in partitioning of the pulp mill extractives between untreated and treated effuent reflect the contrasting nature of the solids present-wood fiber in the case of untreated effluent and biosolids (bacterial biomass) in the case of treated effluent. Because of the high particulate loading typical of this pulp and paper effluent and the hydrophobicity of the effluent extractives, a significant proportion of these organics were removed from the treated effluent by GF/C filtration (Table 1). The compounds remaining in the effluents after filtration are not necessarily truly dissolved. The GF/C filtration may allow the passage of particles as large as 1.5 $\mu \mathrm{m}$. Hydrophobic organics may also be adsorbed to colloidal solids or humic material.

\section{In vivo mosquitofish experiments}

The 96-h LC50 for mosquitofish exposed to untreated effiuent was $31.3 \%$; treated effluent produced no mortality at $100 \%$ concentration. For this reason, the maximum concentration of untreated effluent in experiment 1 was set at $15 \%$. Mortality during mosquitofish experiment 1 was less than $15 \%$ throughout all treatment groups. Mortality during experiment 
FEMALE (normal)

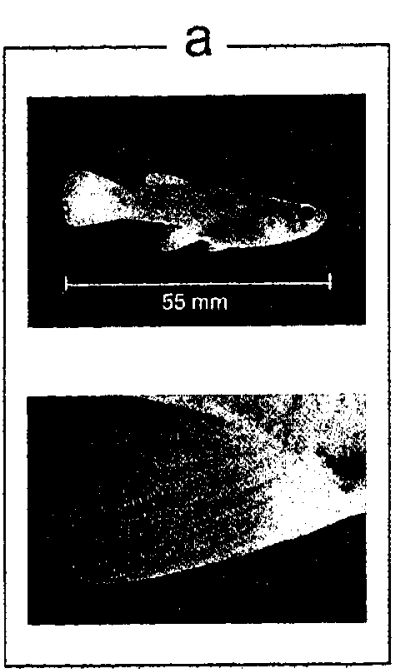

FEMALE (partially masculinized) b

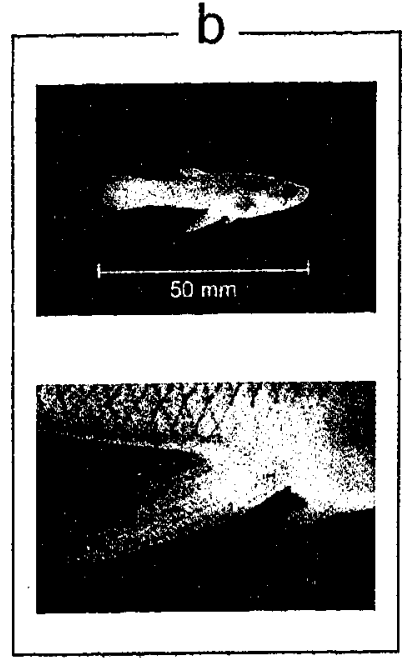

FEMALE ( masculinized)

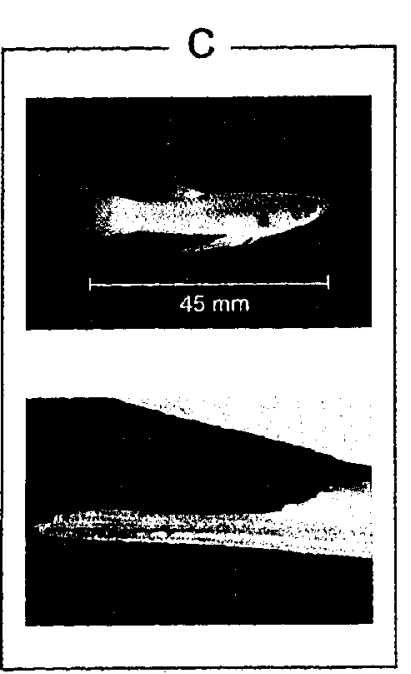

MALE (normal)

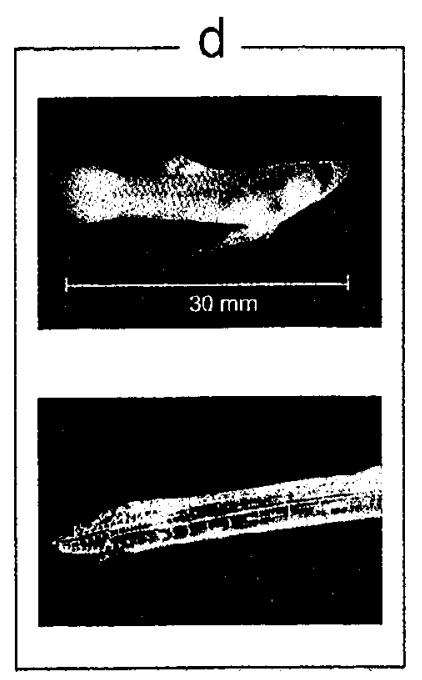

Fig. 1. Mosquitotish anal fin morphology: (a) normal female, (b) partially masculinized, (c) masculinized female, and (d) normal male.

2 was more variable across treatment groups. This coincided with an atypically high effluent solids loading during experiment 2 (total suspended solids averaged $66 \mathrm{mg} / \mathrm{L}$ ) compared with that for experiment 1 (total suspended solids averaged $33.8 \mathrm{mg} / \mathrm{L}$ ). The latter is more representative of the mean annual suspended solids loading. Mortality in the reference treatment of experiment 2 was $16 \%$, whereas filtered and unfiltered effiuent treatments produced mortality rates of 20 and $25 \%$, respectively.

Both treated and untreated effluent caused gonopodium development in female mosquitofish (Fig. 1). In experiment 1 , untreated effluent had a greater gonopodium inducing potential than an equal concentration of secondary-treated effluent (Fig. 2). Treatment of effluent through the aerated stabilization basin reduced the morphogenic response in adult females, as indicated by a decrease in the frequency of masculinization of approximately $25 \%$. However, secondary-treated effluent was still capable of significant induction of gonopodial develop-

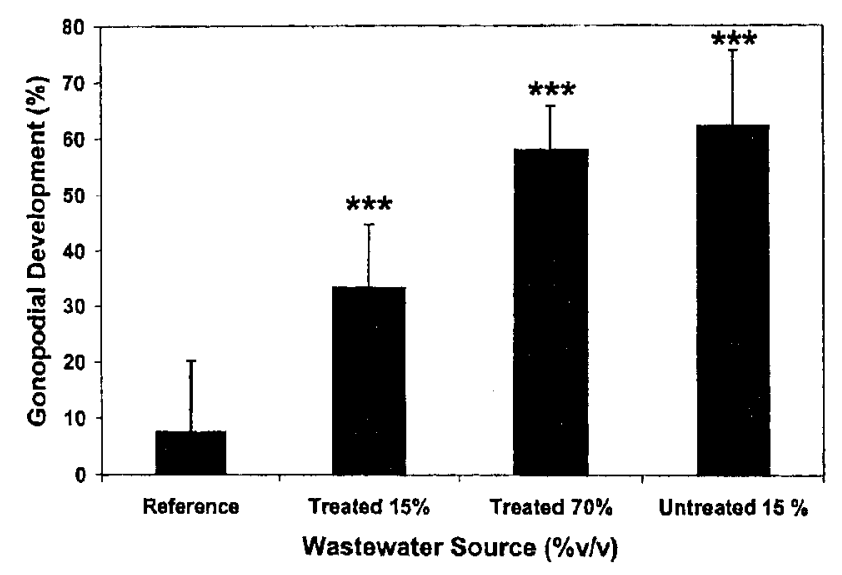

Fig. 2. Mean ( $\pm 95 \%$ confidence interval) of the rates of gonopodial development in female mosquitofish in each tank exposed to various concentrations of treated and untreated effluent $(n=4$ tanks for each bar, $n=5$ fish per tank). Asterisks indicate significant differences from the reference water fish $(* * *=p<0.001) . v / v=$ volumel volume. ment at an environmentally relevant concentration of $15 \%(\mathrm{v} /$ v). A dose response was observed in the two dilutions of treated effluent (Fig. 2). Masculinization was first observed at 7 to $8 \mathrm{~d}$ of exposure and occurred predominantly in the younger (smaller but sexually mature) females. This may be due to the older females being or having been pregnant.

In the second experiment, filtration of treated effluent resulted in a significant decrease in gonopodial morphogenesis (Fig. 3). In the filtered treatment group, only one individual developed a gonopodium. The GF/C filtration removed many of the organic extractives, as they are relatively hydrophobic and adsorbed to suspended solids. Frequencies of gonopodium development in adult females exposed to $15 \%$ unfiltered, treated effluent were relatively consistent across the two experiments (Figs. 2 and 3).

An ethogram conducted during experiment 1 showed that masculinized females exhibited many of the behavioral patterns typical of normal males-that is, chasing nonmasculinized females with gonopodial erection and thrusting. Nonmasculinized females were not observed to demonstrate these behaviors. Male behavior occurred at similar rates across all

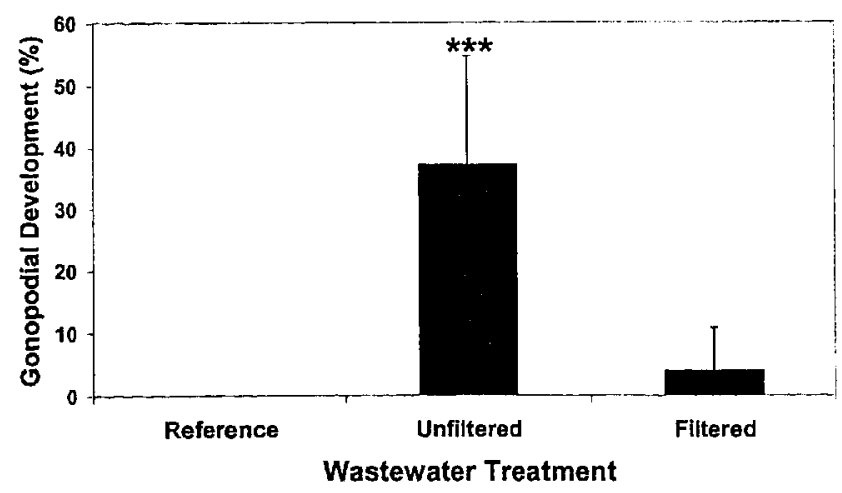

Fig. 3. Mean ( $\pm 95 \%$ confidence interval) rates of gonopodial development in female mosquitofish exposed to $15 \%$ (volume/volume) glass-fiber (type C) filtered and unfiltered treated effluent $(n=4$ tanks for each bar). Asterisks indicate significant differences from the reference water-exposed fish $(* * *=p<0.001)$. 
Table 2. Relative binding affinities of endogenous steroids, environmental sterols, and pulp mill effluent to the androgen receptor in goldfish testes

\begin{tabular}{lc}
\hline Compound & Relative binding (\%) \\
\hline Testosterone & 100 \\
11-Ketotestosterone & 4.7 \\
17 $\beta$-Estradiol & 19.4 \\
$\beta$-Sitosterol & 0.0 \\
Testosterone-equivalent concentration & $(\mathrm{ng} / \mathrm{L})$ in effluent \\
\hline Glass-fiber filtration (combined type C and $\mathrm{F})$ & 57 \\
Solid-phase extraction of filtrate (C18) & 108 \\
\hline
\end{tabular}

treatments where masculinized females were present (including one masculinized control fish). Very rarely was penetration or contact with the nonmasculinized female made, with an overall average (all treatments combined) for masculinized males of only 0.017 observations/individual $/ \mathrm{min}$. Approach and chase were the predominant behaviors displayed ( 1.3 and 1.0 observations/individual $/ \mathrm{min}$, respectively), while display and thrust were less common (0.13 and 0.29 observations/ individual/min, respectively).

\section{In vitro goldfish experiment}

The goldfish testes androgen receptor-binding assay showed the highest affinity for testosterone, while 11-ketotestosterone had relatively low binding affinity (Table 2). Estradiol also showed a significant level of binding using this bioassay. The $\beta$-sitosterol showed no binding at concentrations reflective of the upper range of values measured in our effluent extracts. Treated effluent extracts caused strong androgen receptor (AR) binding in goldfish cytosol (Fig. 4 and Table 2). In comparison, upstream Tarawera River water extracts showed no binding potential to goldfish cytosol.

In contrast to the in vivo mosquitofish assay, both particulate $(\mathrm{GF} / \mathrm{C}, \mathrm{GF} / \mathrm{F})$ and dissolved (C18, solid-phase extraction) organic fractions of the treated effluent had relatively strong binding to components with the cytosol (Table 2). Direct chemical analysis of the extracts used for in vitro exposures showed a similar pattern of organics partitioning to dissolved and particulate fractions (Table 1) as seen in the whole treated effluent samples. Nonetheless, greater binding affinity was found with exposure to the dissolved fraction than to the filtered, particulate fraction. Analysis of extract fractions by liquid chromatography/mass spectrometry did not detect androstenedione or testosterone in either the effluent extracts or the upstream Tarawera River extracts $(<1 \mathrm{ng} / \mathrm{L}$ in the effluent).
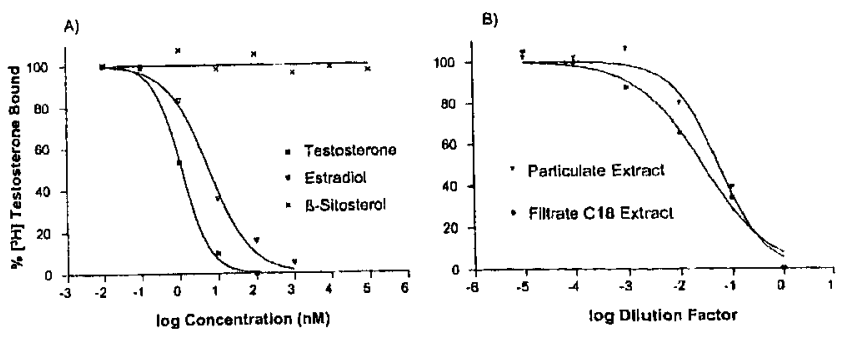

Fig 4. Androgen receptor binding by (A) testosterone, estradiol, and $\beta$-sitosterol and (B) extracts from treated pulp mill effluent extracts. Effluent extracts are in arbitrary dilution factor units with the most concentrated extract $=1$. These extracts represent $20 \mathrm{~L}$ of effluent concentrated to $4 \mathrm{ml}$. GF/C = glass-fiber filter

\section{DISCUSSION}

In this study, a secondary-treated elemental-chlorine-free pulp and paper mill effluent was observed to induce androgenic effects in female mosquitofish; physiologically masculinized females also exhibited male behavioral traits. Both untreated and secondary-treated effluent were capable of inducing the androgenic responses. Secondary treatment of the effluent partially reduced the frequency of masculinization, while filtration of treated effuent almost entirely eliminated it. Enhanced displacement of testosterone from the goldfish testis androgen receptor was observed on exposure to treated effluent extracts. However, this in vitro bioassay was not totally predictive of the mosquitofish response, as binding occurred with both particulate and filtrate extract fractions; mosquitofish did not respond to the effluent filtrate.

Environmentally induced masculinization in mosquitofish was first noted by Howell et al. [13] in a wild population exposed to BKME-contaminated receiving waters in Florida (USA). Their observations constitute one of the earliest documentations of "reproductive-endocrine" effects associated with pulp and paper mill effluent exposure. Results of the present study reporting gonopodial development in adult females are consistent with the findings of Howell et al. [13] and Drysdale and Bortone [15] in that pulp mill effluents were considered to cause androgenic effects. Prior to the Florida field observations of 1980, the induction and development of gonopodia in female Poeciliids in response to androgenic hormones had been extensively researched in the laboratory $[23,30]$. The lab studies clearly showed that exposure to known androgens elicited morphological and behavioral changes like those seen in this and other studies. Howell et al. [13] concluded that a direct-acting androgen in BKME was the most likely mechanistic source for mosquitofish masculinization.

In this study, morphogenesis began within 7 to $8 \mathrm{~d}$ of exposure, with a greater number of younger females developing a gonopodium than older females. Turner [23] observed similar responses and concluded that larger individuals had anal fins "more" fixed in structural pattern. Both male and female mosquitofish have an identical genetic predisposition for gonopodial development; however, it is the absence of endogenous androgenic hormones in the female that prevents development under normal circumstances [25].

In this study, the development of male behavioral patterns accompanied the outward physical changes in females. The behavioral alterations may enhance or even overshadow the potential effects on population integrity from the physiological changes observed. In previous studies, histological examination of female mosquitofish with anal fin modification found no abnormal ovarian tissue development or sex reversal $[13,14]$. In these studies, the ability to copulate and produce offspring also did not appear to be eliminated despite behavioral changes. Howell et al. [13] observed pregnant masculinized females that produced offspring over the summer months, but the fecundity of these individuals was lower than that of unexposed normal females. Thus, the degree to which the masculinization phenomenon impacts on reproduction at the population level is still unclear.

Despite the observations of multiple reproductive lesions in fishes exposed to pulp and paper mill effluents, no consensus exists on the causative agents. Sterols are ubiquitous in pulp and paper mill effluents and have been implicated as possible reproductive toxicants. The removal of these compounds dur- 
ing the pulping process presents great difficulty, as they are hydrophobic and strongly bound to or integrated into the biosolids. Previous data from the Tasman Mill showed only 60\% removal of $\beta$-sitosterol through effluent treatment (M. Tavendale and T.R. Stuthridge, Forest Research, Rotorua, New Zealand, unpublished data). The most abundant sterol in this study, $\beta$-sitosterol, was not found to bind in the androgen receptor assay and would be unlikely to cause the observed effects in either in vitro or in vivo assays. Comparison of the mode of action of pure sterols with that of pulp mill effluents by other researchers has also led to the conclusion that phytosterols are not likely the cause of reproductive dysfunction in fishes exposed to pulp and paper mill effluents [31].

The derivatives of sterols seem the most likely candidates for causing the reproductive effects observed in mosquitofish. Phytosterols can be microbially transformed into $\mathrm{C}_{12}$ steroids $[21,22]$, and microbial removal of the aliphatic side chain of $\beta$-sitosterol and stigmasterol transforms them into androstandienedione and androstenedione, respectively. It should be noted that in the effluent studied here, cholesterol is frequently found in similar quantities to phytosterols and thus is also a potential precursor to steroidal compounds as well. Recently, androstenedione was identified by liquid chromatography/ mass spectrometry as one of two androgen-like compounds within a kraft mill receiving water [24]. River receiving water fractions induced androgen receptor-dependent transcriptional activity in transient transfection cell culture assays. The mechanism of this effect was further verified as being androgenic by directly observed AR binding via immunocytochemical localization of human androgen receptors in cell cultures [32]. Neither androstenedione nor testosterone was found in effiuent extracts in the present study. However, we did not measure many of the other potential steroidal androgens, other than androstenedione and testosterone, that could be potentially produced from the biotransformation of sterols in the effluent. Therefore, the possibility that a sterol derivative is responsible for the observed effect cannot be ruled out.

It was also possible that in vivo biotransformation of an androgen precursor, such as pregnenolone, to a physiologically active androgen, such as testosterone, could account for observed precocious and morphogenic effects. However, other evidence suggests that a precursor in effluent may become transformed into a reproductively active compound by microorganisms existing in the effluent or stream sediment [22]. Parrott et al. [33] observed reduced steroidogenesis in goldfish exposed to a treated pulp mill effluent but failed to find a similar effect in untreated effluent or in any other in-mill waste stream, implying that the active compound(s) were formed during treatment. Settling ponds containing plant products and bacteria could be considered potential steroid generators. However, we saw a significant decrease $(30 \%)$ in rates of mosquitofish masculinization following secondary treatment of the effluent. This coincided with the observed removal of large proportions of most of the measured extractives, with the exception of sterols. The Tasman Mill differs from other mills studied in that the untreated effluent contains thermomechanical pulping effluent that has been aerobically treated in-mill before the various effluent streams are mixed, perhaps explaining this lack of agreement. Thus, it is possible that some of the bioactive compounds were formed in the highly efficient moving bed biofilm reactor system and then were later degraded in the secondary-treated system.

In the in vitro goldfish assay, both the particulate and the dissolved organic effluent fractions had relatively strong androgen receptor-binding potential. The binding in the filtrate extract could have been due to polar nonsteroidal structures or some sort of competitive binding with humic material in the extracts. It is likely that steroids partition in a similar manner to sterols because of their similar hydrophobicity and would be mostly in the particulate fraction. Regardless of the nature of the AR-binding compound(s), it is apparent that these compounds are not acting in an androgenic fashion in mosquitofish. These results demonstrate the danger of extrapolating in vitro assays to possible in vivo effects, and we suggest that in vitro assays must always be validated with studies of live organisms. Other reasons for the discrepancy between bioassays may include the propensity of the goldfish-AR bioassay to bind estrogens in vitro or the requirement of physiological enzymes such as aromatase to render compounds active.

Interpretations regarding the goldfish testes AR bioassay were clouded by the binding of nonandrogenic structures to the goldfish testes cytosol used herein. Wells and Van Der Kraak [27] found nearly identical binding affinities for 11 ketotestosterone and estradiol as were seen in this study. Though androgen receptor is undoubtedly present, the potential for sex steroid-binding protein to be present certainly exists and may explain the binding of estrogen in this assay. The previous study [27] also examined the binding affinity of a number of other compounds not examined here, including androstenedione. Androstenedione had a binding affinity that was about half that of testosterone, so it would be likely to also bind strongly in our assay if it were present. It can be concluded that structures were present in the effluent that were capable of displacing testosterone from the goldfish testes cytosol. We would also hypothesize that a high probability exists that these unknown structures were steroidal.

Although these data suggest a direct androgenic mechanism resulting in masculinization of some fish species, other possible mechanisms exist. Stressors/factors other than the direct effect of androgenic hormones are capable of inducing gonopodial morphogenesis in females; these include treatment with pregnant mare serum or chorionic gonadotropin, incomplete hypophysectomy, old age, parasites, and Ichthyophonus fungal infection, as cited in Howell et al. [13]. Such stressors may act either directly on the ovaries or indirectly through the pituitary gland. Increased levels of gonadotropin released from the pituitary could potentially increase ovarian androgen production if the conversion of testosterone to estradiol was limited. At the level of the ovaries, compounds in effluent may directly cause the inhibition of the conversion of testosterone to estradiol. Because of the complex nature of the hypothalamo-pituitary-gonadal axis, further study is required to resolve a mechanism.

The treated effluent used in this study did not elicit reproductive effects in either male or female rainbow trout exposed in experimental ponds during midmaturation [28,29]. However, when exposure was initiated prior to gonadal maturation, subtle changes, such as reduction in egg and gonad size, were observed in females [29]. The effects on females were linked to steroid hormone reductions and did not appear to be strongly androgenic, as no male secondary sex characteristics were observed in females. Male trout were not impacted at all, with the exception of the induction of plasma VTG and liver mixedfunction oxygenase activity [29]. 
Although this study focused on androgenicity, pulp and paper mill effluent has also shown the potential to act in an estrogenic fashion. Tremblay and Van Der Kraak [19] observed the induction of VTG in rainbow trout in response to effluent exposure, while Mellanen et al. [18] observed the induction of VTG mRNA. The effluent used in our study induced trout VTG in only one of five experiments [29,34], so this does not appear to be a consistently occurring phenomenon. Pulp mill effluents are known to contain estrogenic nonionic surfactants in varying quantities [35]. The nature of pulp and paper effluents is highly variable, even within a single mill [29], and it is highly unlikely that the plethora of reproductive effects documented in fishes were caused by a single androgenic or estrogenic mechanism. However, strong evidence indicates that such mechanisms do constitute a component of observed effects.

Since the initial studies on mosquitofish masculinization in the 1980s, the pulp and paper industry in general has undergone significant process and treatment improvements designed to reduce toxicity, biochemical oxygen demand, solids, and organochlorines. The main changes are the nearly universal adoption of secondary treatment of effluents (predominantly aerobic) and the replacement of molecular chlorine with alternate bleaching compounds and methods. These major changes, coupled with other minor improvements in technology and a generally improved environmental awareness, have produced dramatic improvements in effluent quality. Despite these changes, modern effluents can still produce subtle reproductive alterations in fishes. The results presented here demonstrate that an elemental-chlorine-free, secondary-treated pulp mill effluent is also capable of inducing androgenic responses in both in vivo and in vitro bioassays. Future work will seek to determine the identity, mechanism of action, and source of the endocrine-modulating compounds in order to aid in the formulation of effluent treatment solutions.

Acknowledgement-Funding for this research was provided by the Arthur and Aenne Feindt Foundation of Germany, Foundation for Research Science and Technology of New Zealand, and by the Tasman Mill. The authors wish to acknowledge the assistance of $\mathrm{L}$. Chiaroni, M. Harris, N. Marvin, R. Hunter, R. Donald, N. Ling, I. Hogg, and B. O'Brien.

\section{REFERENCES}

1. Van Der Kraak GJ, Munkittrick KR, McMaster ME, Portt CB, Chang JP. 1992. Exposure to bleached kraft pulp mill effluent disrupts the pituitary-gonadal axis of white sucker at multiple sites. Toxicol Appl Pharmacol 115:224-233.

2. McCarthy LH, Munkittrick KR, Blunt BR, Van Der Kraak GJ, Wood CS, Parrott J. 2002. Steroid levels in goldfish exposed to pulp mill effluent. In TR Stuthridge TR, van den Heuvel MR, Marvin NA, Slade AH, Gifford J, eds, Environmental Impacts of Pulp and Paper Waste Streams. SETAC, Pensacola, FL, USA (in press).

3. Munkittrick KR, McMaster ME, Portt CB, Van Der Kraak GJ, Smith IR, Dixon DG. 1992. Changes in maturity, plasma sex steroid levels, hepatic mixed function oxygenase activity, and the presence of external lesions in lake whitefish (Coregonus clupeaformis) exposed to bleached kraft mill effluent. Can J Fish Aquat Sci 49:1560-1569.

4. Munkittrick KR, Van Der Kraak GJ, McMaster ME, Portt CB. 1992. Reproductive dysfunction and MFO activity in three species of fish exposed to bleached kraft mill effluent at Jackfish Bay, Lake Superior. Water Pollut Res J Can 27:439-446.

5. Munkittrick KR, Van Der Kraak GJ, McMaster ME, Portt CB. 1992. Response of hepatic MFO activity and plasma sex steroids to secondary treatment of bleached kraft pulp mill effluent and mill shutdown. Environ Toxicol Chem 11:1427-1439.
6. Andersson T, Förlin L, Härdig J, Larsson ÅA. 1988. Physiological disturbances in fish living in coastal water polluted with bleached kraft pulp mill effuents. Can J Fish Aquat Sci 45:1525-1536.

7. Tana J, Nikunen E. 1986. Impact of pulp and paper mill effluent on egg hatchability of pike (Esox lucius L.). Bull Environ Contam Toxicol 36:738-743.

8. Vuorinen M, Vuorinen PJ, 1987. Effects of bleached kraft mill effluent on early life stages of brown trout (Salmo trutta L.). Ecotoxicol Environ Saf 14:117-128.

9. McMaster ME, Van Der Kraak GJ, Portt CB, Munkittrick KR, Sibley PK, Smith IR, Dixon DG. 1991. Changes in hepatic mixedfunction oxygenase (MFO) activity, plisma steroid levels and age at maturity of a white sucker (Cafostomas commersoni) population exposed to bleached kraft mill effluent. Aquat Toxicol 21 : $199-218$.

10. Larsson DGJ, Hällman H, Förlin L. 2000. More male fish embryos near a pulp mill. Environ Toxicol Chem 19:2911-2917.

11. Kovacs TG, Gibbons JS, Tremblay LA, O' Connor BI, Martel PH, Voss RH. 1995. The effects of a secondary-treated bleached kraft mill effuent on aquatic organisms as assessed by short-term and long-term laboratory tests. Ecotoxicol Environ Saf 31:7-22.

12. Larsson DGJ. 2000. Endocrine disruption in fish. Sex ratios, secondary sex characters and estrogen-induced proteins. PhD thesis. University of Göteborg. Göteborg, Sweden.

13. Howell WM, Black DA. Bortone SA. 1980. Abnormal expression of secondary sex characters in a population of mosquitofish, Gumbusia affinis holbrooki: Evidence for environmentally-induced masculinization. Copeia 4:676-681

14. Rosa-Molinar E. Williams CS. 1984. Notes on fecundity of an arrhenoid population of mosquitofish. Northecast Gulf Sci 7:121125.

15. Drysdale DT, Bortone SA. 1989. Laboratory induction of intersexuality in the mosquitofish, Gambusia affinis, using paper mill effluent. Bull Environ Contam Toxicol 43:611-617.

16. Sharples AD. 1998. Effects of pulp mill effluent on goldfish in the Waikato River before and after changes to the bleach plant process. PhD thesis. University of Auckland, Auckland, New Zeaprocess.

17. Soimasuo MR, Karels AE, Leppänen H, Santti R, Oikari AOJ. 1998. Biomarker responses in whitefish (Coregonus lavaretus L. s.l.) experimentally exposed in a large lake receiving effluents from pulp and paper industry. Arch Environ Contam Toxicol 34: $69-80$.

18. Mellanen P, Soimasuo M, Holmbom B, Oikari A, Santti R. 1999. Expression of the vitellogenin gene in the liver of juvenile whitefish (Coregonus lavaretus L-s.l.) exposed to effluents from pulp and paper mills. Ecotoxicol Environ Saf 43:133-137.

19. Tremblay L, Van Der Kraak GJ. 1999. Comparison between the effects of the phytosterol $\beta$-sitosterol and pulp and paper mill effluents on sexually immature rainbow trout. Environ Toxicol Chem 18:329-336.

20. Hewitt LM, Parrott JL, Wells KL, Calp MK, Biddiscombe S, McMaster ME, Munkittrick KR, Van Der Kraak GJ. 2000. Characteristics of ligands for the Ah receptor and sex steroid receptors in hepatic tissues of fish exposed to bleached kraft mill effiuent. Environ Sci Technol 34:4327-4334.

21. Howell WM, Denton TE. 1989. Gonopodial morphogenesis in female mosquitofish, Gambusia affinis affinis, masculinized by exposure to degradation products from plant sterols. Environ Biol Fish 24:43-51.

22. Denton TE, Howell WM, Allison JJ, McCollum J, Marks B. 1985. Masculinization of female mosquitofish by exposure to plant sterols and Mycobacterium smegmatis. Bull Environ Contam Toxicul 35:627-632.

23. Turner CL 1941. Gonopodial characteristics produced in the anal fins of females of Gambusia affinis affinis by treatment with ethinyl testosterone. Biol Bull 30:371-383.

24. Jenkins R, Angus RA, McNatt H, Howell WM, Kemppainen JA, Kirk M. Wilson EM. 2001. Identification of androstenedione in a river containing paper mill effuent. Environ Toxicol Chem 20: $1325-1331$.

25. Turner CL. 1941. Morphogenesis of the gonopodium in Gambusia affinis affinis. J Morphol 69:161-185.

26. Bortone SA, Davis WP, Bundrick CM. 1989. Morphological and behavioral characters in mosquitofish as potential bioindication of exposure to kraft mill effluent. Bull Environ Contam Toxicol $43: 370-377$. 
27. Wells K, Van Der Kraak GJ 2000. Differential binding of endogenous steroids and chemicals to androgen receptors in rainbow trout and goldfish. Environ Toxicol Chem 19:2059-2065.

28. van den Heuvel MR, Ellis RJ, Tremblay LA, Stuthridge TR. 2002 Exposure of reproductively maturing rainbow trout to a New Zealand pulp and paper mill effluent. Ecotoxicol Environ Saf 51: 65-75.

29. van den Heuvel MR, Ellis RJ. 2002. Timing of exposure to a pulp and paper effluent influences the manifestation of reproductive effects in rainbow trout. Environ Toxicol Chem 21:23382347.

30. Turner CL. 1942. Morphogenesis of the gonopodial suspensorium in Gambusia affinis and the induction of male suspensorial characters in the female by androgenic steroids. $J$ Exp Biol 91:167193.

31. Van Der Kraak GJ, Munkittrick KR, McMaster ME, MacLatchy DL. 1998. A comparison of bleached kraft mill effuent, $17 \beta$ estradiol, and $\beta$-sitosterol effects on reproductive function in fish. In Kendall RJ, Dickerson RL, Giesy JP, Suk WA, eds, Principles and Processes for Evaluating Endocrine Disruption in Wildlife. SETAC, Pensacola, FL, USA, pp 249-265.

32. Parks LG, Lambright CS, Orlando EF, Guillette LJ, Ankley GT, Gray LE. 2001. Masculinization of female mosquitofish in kraft mill effluent-contaminated Fenholloway River water is associated with androgen receptor agonist activity. Toxicol Sci $62: 257-267$.

33. Parrott JL, Jardine JJ, Blunt BR, McCarthy LH, McMaster ME Munkittrick KR, Wood CS, Roberts J, Carey JH. 2000. Comparing biological responses to mill process changes: A study of steroid concentrations in goldfish exposed to effluent and waste streams from Canadian pulp mills. Proceedings, 4th International Conference on Environmental Fate and Effects of Pulp and Paper Mill Wastewaters, Helsinki, Finland, June 12-15, p 145.

34. Ellis RJ. 2001. An assessment of endocrine disrupting potential of a New Zealand pulp and paper mill effluent using rainbow trout (Oncorhynchus mykiss) and mosquitofish (Gambusia affinis). PhD thesis. University of Waikato, Hamilton, New Zealand.

35. Lee HB, Peart RE. 1999. Occurrence of nonylphenol ethoxylates and their metabolites in Canadian pulp and paper mill effluents and sludge. Water Qual Res J Can 34:633-652. 